\title{
El Salvador: La Circular Ripalda, una Escuela sin Religión
}

\author{
Julián González-Torres
}

A mediados de 1880, el Estado de El Salvador sancionó un decreto que no tenía precedentes en la historia del país centroamericano: los gobernadores departamentales debían prohibir la enseñanza del catecismo católico - el Catecismo del padre Ripalda - en las escuelas primarias de la República. Los alcaldes municipales y los gobernadores departamentales encarnaban los tentáculos más visibles del incipiente poder estatal, por lo que los funcionarios de la Secretaría de Instrucción Pública esperaban que el decreto se cumpliera al pie de la letra en todos los pueblos.

El presidente Rafael Zaldívar - que gobernaba desde 1876- quiso ensanchar un tipo de modernidad laica. El compromiso con esta modernidad secular implicó no sólo la crítica a la modernidad católica que había predominado durante el siglo XIX. Implicó también la asunción de una "filosofía moderna" que pregonaba la libertad de conciencia religiosa, la pluralidad de creencias religiosas, la tolerancia, la autonomía del pensamiento y la neutralidad del Estado en materia religiosa. La laicización de la escuela pública se complementó con una reforma. La reforma educativa de 1887 ratificó la exclusión del credo católico de las escuelas públicas. Al mismo tiempo, aprobó materias y textos de lectura de corte más secular. Si el Catecismo de Ripalda apelaba a nociones como "cielo", "infierno" o "pecado", los textos nuevos ofrecían un tipo de narrativa que versaba sobre la vida cotidiana, situaciones y problemas comunes de una vida en familia, y situaciones y preguntas típicas de un niño. Las nuevas lecturas provocaban más sensibilidad hacia el entorno. La nueva pedagogía - de raíz pestalozziana y froebeliana - trazó otros senderos para el aprendizaje de los niños: señalaba que se debía partir de la experiencia inmediata del infante y desde allí avanzar, de manera progresiva, hacia el afianzamiento de los conocimientos. Así comenzó la era de la escuela laica en El Salvador.

No obstante, los gobiernos de Rafael Zaldívar y de Francisco Menéndez - quien sucedió a Zaldívar en 1885 por medio de un golpe de Estado - debieron lidiar con las fuerzas más conservadoras de la sociedad. Tuvieron que plantarse incluso ante los mismos funcionarios del Estado. En otra circular, siempre en el año 1880,

Julián González Torres, Universidad Centroamericana José Simeón Cañas, El Salvador, C. A.

Recibido: 15 de septiembre de 2015. 
el subsecretario de Instrucción Pública amenazó a los gobernadores con cobrarles doscientos pesos en concepto de multa si en sus respectivas jurisdicciones no hacían efectiva la prohibición de enseñar la religión en las escuelas públicas.

El Estado salvadoreño libró una contienda con la Iglesia católica en el campo de la opinión pública. Los sectores católicos más conservadores afirmaron que la religión significaba la unidad del pueblo salvadoreño y que cualquier decisión del Estado conducente a mermar la hegemonía moral de la religión católica arruinaría las buenas costumbres y sembraría el caos en la sociedad. Afirmaban que la escuela laica era una herejía. Por su parte, los funcionarios del Gobierno creían que era el comienzo de una época laica y secular. El Salvador no se quedó al margen de las transformaciones liberales del último tercio del siglo XIX. Fueron procesos reformistas que redefinieron el mapa político de las repúblicas que surgieron tras los procesos de independencia durante las primeras décadas del siglo XIX.

A continuación se presenta al lector la transcripción de la Circular Ripalda y la ilustración de la fuente original. ${ }^{1}$

\section{Notas}

1En la transcripción se ha respetado en su integridad la fuente original.

CIRCULAR.

Palacio Nacional:

San Salvador, Junio 15 de 1880.

Sr. Gobernador del Departamento de...

El Catecismo cristiano del Señor Ripalda, cuyo estudio ó aprendizaje está implantado en las escuelas primarias de toda la República, es fuente y orígen de preocupaciones funestísimas que, pesando sobre la conciencia de los niños y aun de la juventud en general, estorban y entorpecen el libre desarrollo de sus creencias, enmordazando el espíritu en su vuelo hácia el cielo esplendente de la Filosofía moderna, que predica el libre exámen como dogma redentor de la conciencia y enaltecedor eterno de la dignidad del hombre. Ahora bien, el Supremo Gobierno, penetrado de la evidencia de esta verdad innegable, y decidido como está á romper con las aciagas tradiciones de la devota educacion, como rémora constante y pertinaz que tanto ha perjudicado y perjudica aun la condicion moral del individuo, no puede menos que prohibir en las escuelas primarias la enseñanza de las doctrinas que contiene la citada obrita del Señor Ripalda.

Por tanto, inmediatamente que U. reciba la comunicacion presente, espedirá sus órdenes á efecto de que se dé estricto cumplimiento á la prohibicion mencionada, prescribiendo que aquel estudio sea sustituido por el de una obra de moral, como la del Señor Carreño, y la Cartilla del Ciudadano, puesto que honrados ciudadanos, y no rezadores, necesita el pais.

Soy de U. muy atento S. servidor.

El Sub-Secretario;

Antonio J. Castro. 


\section{Circular Ripalda. San Salvador, 15 de junio de 1880}

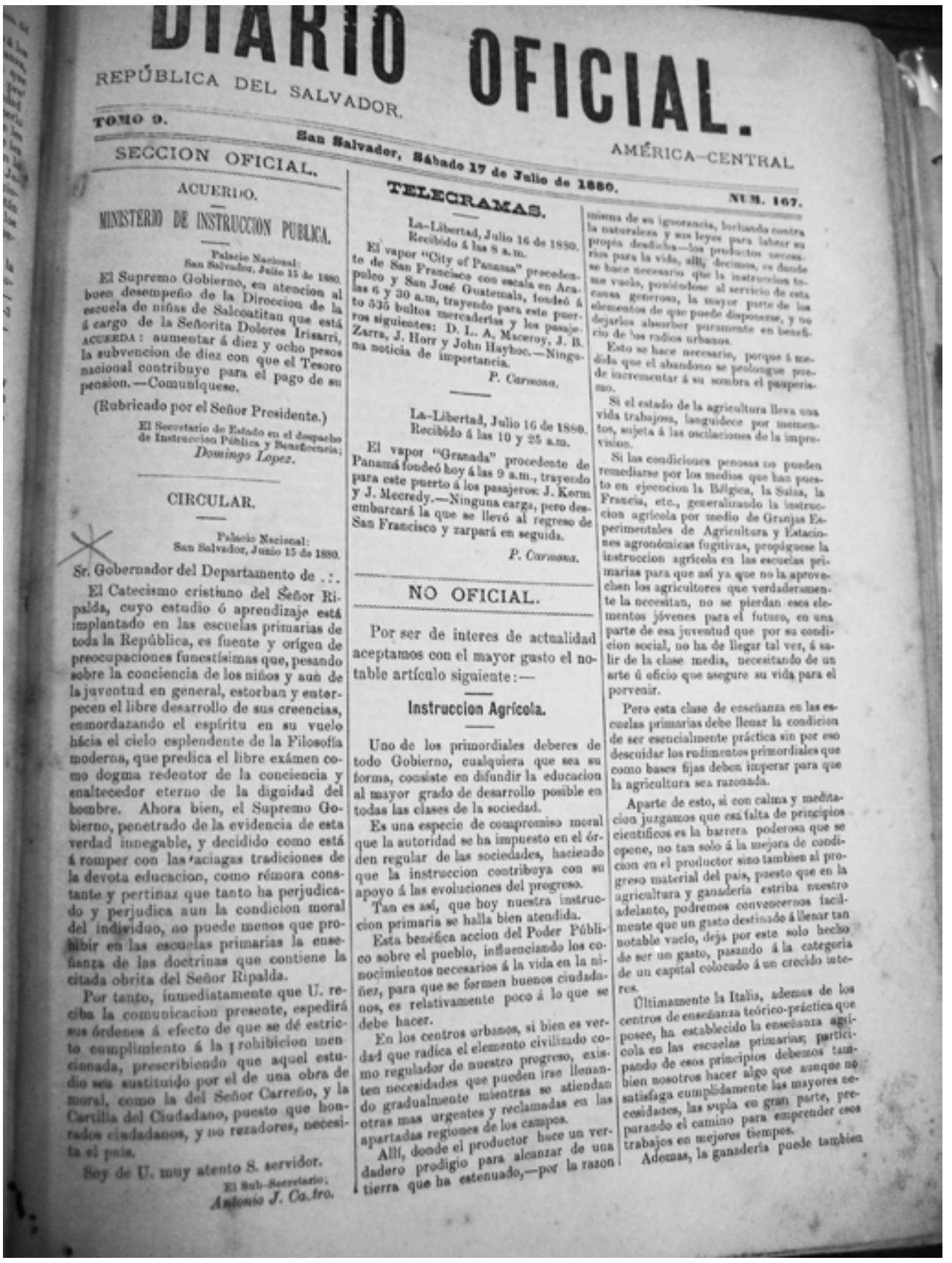

Fuente: Diario Oficial. República del Salvador, tomo 9, núm. 167. San Salvador, sábado 7 de julio de 1880. 